*Pre-print version. Please cite from the final version in Colin Marshall ed. Comparative Metaethics: Neglected Perspectives on the Foundations of Morality. New York: Routledge, 2019.

\title{
Sontag on Impertinent Sympathy and Photographs of Evil
}

\author{
Sean T. Murphy
}

Let the atrocious images haunt us. Even if they are only tokens, and cannot possibly encompass most of the reality to which they refer, they still perform a vital function. The images say: This is what human beings are capable of doing-may volunteer to do, enthusiastically, self-righteously. Don't forget.

Susan Sontag, Regarding the Pain of Others

\section{Introduction}

Although her work is not often discussed in the typical venues for academic philosophy, Susan Sontag is likely to be a name that many among our small community would recognize. Outside of philosophy her thought has been key to understanding the dynamical nature of visual culture throughout the $20^{\text {th }}$ century and its impact on the modern human condition. As such, she's garnered the attention of scholars across various fields, from art history to cultural and media studies. Inside philosophy, however, one gets the sense that she is treated as a literary aesthete, which might explain why philosophers have not paid her work the attention it deserves. This chapter attempts to correct for this undeserved neglect by injecting Sontag's voice into one of the most interesting and theoretically complex areas of academic philosophy; namely, contemporary metaethics.

The text that will be the focus of this essay is Sontag's late book Regarding the Pain of Others (henceforth RPO). The subject matter of the book-the history of photographic representations of war-allows for the natural organization of her metaethical insights into two rough clusters of views: one deals with issues in moral epistemology (specifically moral perception), the other with the moral and epistemic value of human sentiments in general, and our sentimental or emotional reactions to misery and suffering, in particular. Along the way we will see that her views on these matters raise interesting questions about the relationship between aesthetics and 
ethics. In particular, Sontag raises questions about the moral value of our engagement with, and reactions to photographs.

With respect to moral epistemology, Sontag holds that we can gain knowledge of moral propositions on the basis of perception. What is unique about Sontag's view is that contrary to other moral perception theorists (e.g. Blum 1994), she thinks we can directly acquire general moral knowledge via perception, i.e. knowledge of the following sort of proposition: "Human beings everywhere do terrible things to each other" (Sontag 2003, 116). ${ }^{1}$ While we can sometimes acquire this kind of general moral perceptual knowledge by direct confrontations with reality, it is part of Sontag's view that photographs are particularly well-suited to this purpose. ${ }^{2}$ I will argue that, for Sontag, it is in virtue of their status as aesthetic objects that photographs can serve this moral-epistemic purpose.

We find a clear expression of the second metaethical insight in the following passage in $R P O$, where she discusses our emotional responses to photographs of the suffering of war:

So far as we feel sympathy, we feel we are not accomplices to what caused the suffering. Our sympathy proclaims our innocence as well as our impotence. To that extent, it can be (for all our good intentions) an impertinent-if not an inappropriate-response (Sontag 2003, 102).

This passage raises two problems for any view which gives sympathy or compassion pride of place in the foundations of moral value and action. I call these problems The Innocence Problem and The Impotence Problem.

Seeing a photograph of a child covered in napalm might cause me to have a certain sentimental reaction, like feeling sympathy or compassion for the child. Those

\footnotetext{
${ }^{1}$ As I will argue, it is important for the uniqueness of Sontag's view that we are able to acquire general moral perceptual knowledge directly, since other moral perception theorists might agree with her that we can acquire general moral knowledge via moral perception, but they may in turn say that we can only do this indirectly.

${ }^{2}$ In her 2011, Sarah McGrath makes the point that pictures are often thought to be good tools of moral conversion on the basis that they can present us with actual instances of whatever moral practice it is that we are concerned with, and allow us to draw some "general conclusions in response" (McGrath 2011, 268). There is some reason to think that perhaps her view would lend itself to the same reading I provide of Sontag here.
} 
inclined towards sympathy- or compassion-based approaches to ethics take this to be a good thing, some sign of my having the right sorts of values and being in the right relation to my fellow human beings. Sontag, however, argues that there are many cases where having these sentiments can be both morally and epistemically problematic. She thinks that our sentimental responses often presume our innocence and our impotence in cases where we in fact are guilty and it is within our power to do something. For Sontag, it follows that sometimes the content of our emotional responses is false: it can seem that it is part of the content of sympathy that the person who feels sympathetic is innocent and impotent, when neither is in fact the case. So while some part of the content of our sympathetic response to suffering might be accurate or true, another part is not.

In the next section I will offer a summary of $R P O$ and provide textual support for the two metaethical insights that I attribute to Sontag. Section 3 discusses work on moral perception. In section 4 I set Sontag's views on moral perception and moral knowledge against the literature, and argue that she gives us good reason to think that we have some general moral perceptual knowledge. Section 5 treats The Innocence Problem and The Impotence Problem. I introduce the problems and argue that each proves troublesome for some aspects of moral sentimentalism. I then offer some additional support for Sontag's worries in the form of a historical analogue of her view found in the work of another $2 \mathrm{O}^{\text {th }}$ century voice neglected by most metaethicists: Theodor Adorno. Finally, I consider how the moral sentimentalist might respond.

2. The metaethical and aesthetic insights of Regarding the Pain of Others

In $R P O$, Sontag considers the human fascination with depictions of the misery and ruin wrought by war. She examines the ways in which violence and cruelty have been artistically represented in various media, including painting and film. But her main focus is on the practice of war photography that began with the Crimean War, and achieved its greatest ethical relevance during the Vietnam War, a moment in history when "war photography became, normatively, a criticism of war" (Sontag 2003, 65). She also discusses photographic representations of the more recent conflicts in the Balkans and the Middle East. 
Her reflections on these photographs and the historical reality they represent are primarily concerned with their ethical and aesthetic value. On the ethical side of things, she is concerned with familiar questions about the status of moral knowledge, how that knowledge figures in moral motivation, and, relatedly, the moral value of our sentimental reactions to the pain and misery of others. One of her guiding questions is: "[what] to do with such knowledge that photographs bring of faraway suffering?" (Sontag 2003, 99). This is a question she believes we all must ask, and one that becomes especially pertinent in a modern condition where images of violence proliferate. The status of this knowledge will be discussed later in this chapter. For now, it is important that we notice the connection that Sontag draws between knowledge, emotion, and action in her discussion of what we, the viewers, are to do with these photographs.

A fruitful way to consider what Sontag says on this score is to compare $R P O$ with her earlier, well-known collection of essays, On Photography. In doing so we notice a marked difference in what she says about "the ethical value of an assault by images" (Sontag 2003, 117). In her earlier work, Sontag was skeptical about the moral credentials of photographs, stating that "[the] ethical content of photographs is fragile" (Sontag 1977, 21). In the same essay ("In Plato's Cave"), she touches on the "limit of photographic knowledge of the world," noting that while the knowledge acquired by seeing photographs "can goad conscience, it can, finally, never be ethical or political knowledge" (Sontag 1977, 24).

By the time she is writing $R P O$, however, her skepticism has subsided. She reflects on this change in her view in the following passage.

In the first of the six essays in On Photography (1977), I argued that while an event known through photographs certainly becomes more real than it would have been had one never seen the photographs, after repeated exposure it also becomes less real. As much as they create sympathy, I wrote, photographs shrivel sympathy. Is this true? I thought it was when I wrote it. I'm not so sure now (Sontag 2003, 105).

Throughout her career she was preoccupied by thoughts about the relationship between photographs of the evil acts that human beings commit towards each other and the emotions they stir in the viewer. Her initial worry was that a sympathetic or 
compassionate response to the photographs, while appropriate, was not of much practical value. This worry is still present in $R P O$. "Compassion," she says "is an unstable emotion. It needs to be translated into action, or it withers" (Sontag 2003, 101). This claim is related to the challenge raised against moral sentimentalism. There are a certain class of moral emotions - sympathy and compassion in particular-that are morally problematic for the reason that (a) their content is false or illusory and (b) they do not always motivate agents in the appropriate ways. However, this claim does not apply to all moral emotions, nor does Sontag think, as she once did, that being inundated with images of war threatens to diminish our moral sensibility and our degree of moral receptivity to the pain of others.

People don't become inured to what they are shown-if that's the right way to describe what happens-because of the quantity of images dumped on them. It is passivity that dulls feeling. The states described as apathy, moral or emotional anesthesia, are full of feelings; the feelings are rage and frustration (Sontag 2003, 102).

Before diving into the details of the metaethical insights contained in $R P O$, we should also note what Sontag says about the aesthetic value of the photographs she is interested in, since this will bear on the discussion of moral perception which follows.

Sontag suggests that war photographs are their own unique sort of aesthetic object. Their uniqueness lies in the fact that it can be inappropriate to take up a purely aesthetic attitude towards them. They are also the sort of aesthetic object whose nature as aesthetic is constituted by a set of properties other than what are thought to be classically aesthetic properties. To bring out this second point, Sontag remarks on the commonly held belief that "to find beauty in war photographs seems heartless" (Sontag 2003, 75-6). War photographs, she says, cannot be "too much like art" (Sontag 2003, 76). Likewise, "a beautiful photograph drains attention from the sobering subject and turns it toward the medium itself, thereby compromising the picture's status as a document" (Sontag 2003, 77).

The question naturally arises: if it is inappropriate for war photographs to appear too much like art, then what makes them aesthetic objects? One answer to this 
question is that photographs are aesthetic in the sense that they are the result of a creative act. Although rather crude, this way of thinking about them would speak to one of the reasons we might appreciate seeing a war photograph: we appreciate the feat of someone actually capturing that particular moment. This would be a kind of aesthetic appreciation of the creative act, and what the photographer did to get themselves in the position to pull that act off, rather than an aesthetic appreciation of the content of the image. When we focus on the creative act of the photographer, however, we come face-to-face with a central question in the aesthetics of photography, namely, the question of realism.

The photographic realist claims that photographs are transparent to the world. ${ }^{3}$ When you see a photograph of a screaming child covered in napalm running through her village streets, you really see that child in that condition. That is, you see the world, and not just a photograph of the world. Sontag is torn between her conviction that something like realism must be true, and the idea that every photograph is the result of a creative act, an action that occurs at a certain time, in a certain place, from a certain perspective. This tension is seen in the following two passages.

Photographs had the advantage of uniting two contradictory features. Their credentials of objectivity were inbuilt. Yet they always had, necessarily, a point of view. They were a record of the real-incontrovertible, as no verbal account, however impartial, could be-since a machine was doing the recording. And they bore witness to the real-since a person had been there to take them (Sontag 2003, 26).

[The] photographic image, even to the extent that it is a trace (not a construction made out of disparate photographic traces), cannot be simply a transparency of something that happened. It is always the image that someone chose; to photograph is to frame, and to frame is to exclude (Sontag 2003, 46).

\footnotetext{
${ }^{3}$ For the classic defense of this view, see Walton 1973.
} 
The very thing that renders war photographs objects worthy of some kind of aesthetic appreciation equally jeopardizes their epistemic credentials. This problem of photographic choice raises the question of the status of any objective knowledge acquired through seeing a photograph. As an exegetical matter, we must ask in which direction Sontag leans: are photographs objective records 'of the real' or is what they depict always a reality seen from a particular point of view, and therefore not strictly speaking 'objective' at all?

For the time being, I will run with the idea that Sontag, though of a mixed mind, is committed to the idea of war photographs as records of the real (even if they are not direct transparencies of what they represent). The aesthetic value of such photographs is therefore not to be fully accounted for by appealing to the creative act of the photographer, nor is it proper to say that what they record has the property of being beautiful. Thus, the best candidate for a view of the aesthetic value of documentary war photographs takes their aesthetic value to be primarily a matter of their cognitive value. A documentary war photograph succeeds aesthetically, that is, succeeds in accordance with the kind of aesthetic object that it is, when it presents the viewer with a representation of war that can be used to ground beliefs about the world that are conducive to knowledge about the world. ${ }^{4}$

But what sorts of knowledge about the world do war photographs ground? Sontag's answer is that the most significant kind of knowledge we get from looking at war photographs is moral knowledge-and not just any kind of moral knowledge, but knowledge of general moral propositions such as "human beings everywhere do terrible things to one another" (Sontag 2003, 116). This suggests that Sontag's settled view is that the aesthetic value of war photographs is exhausted by the extent to which they add to the viewer's reservoir of moral knowledge. In doing so, they provide the cognitive benefit of helping agents reach what she calls "moral and psychological adulthood" (Sontag 2003, 114). I will have more to say about how their status as aesthetic objects contributes to these epistemic and moral gains. But first we must consider

4 The problem of the frame implies that photographs are always more than just direct representations. It would be an overly simplistic view of Sontag's many reflections to say that she subscribes wholeheartedly to photographic realism. Moreover, it is precisely because photographs are aesthetic objects that they can do more than just directly represent. Thanks to Michael A. Rosenthal for reminding me to appreciate the many complexities in Sontag's views. 
Sontag's claim that we can acquire knowledge of general moral propositions by seeing photographs. To do this, we need to examine her view of moral perception.

3. Moral perception and moral knowledge

For what follows, it will help to review some of the general features of moral perception theory. Let us assume that a lot of what gets photographed during war and smaller conflict are states of affairs that morally ought not to be. Setting aside metaphysical questions about the nature of moral values (real? anti-real? irreal?), let us focus on the epistemological question of how we know that what these photographs show is a reality that morally ought not to be. In virtue of what can we be confident that utterances of this sort are true?

Moral epistemology addresses questions about how we come to know what is morally good and bad, what morally ought and ought not to be, or what we morally ought and ought not to do. To chop things rather roughly, philosophers will usually offer either a rationalist or an empiricist moral epistemology. ${ }^{5}$ The rationalist can claim that we come to know the morally good and bad through a priori reasoning, innately, or because what is morally good and bad is self-evident, something we know via intuition. The empiricist, on the other hand, holds that moral knowledge is a species of empirical knowledge. Since empirical knowledge is the sort of thing we typically acquire via perception, one kind of empiricist claims that we have perceptual moral knowledge. Sontag's remarks in RPO align her more closely with the empiricist.

The literature on moral perception has been steadily growing over the last several years (Blum 1994; McGrath 2004; Wright 2007; Cullison 2009; Dancy 2010; McBrayer 2010; Audi 2013. For a skeptical view see Väyrynen 2018). Those who are attracted to the idea of moral perception believe, as Jen Cole Wright puts it, "that there are genuine perceptual states that have moral (or morally relevant) content" (Wright $2007,2)$. If this can be shown, then it is plausible to think that at least some moral knowledge can be had by way of perception. Furthermore, if the view succeeds, then our perceptual experiences can be cited as evidence for some of our moral beliefs. "How

${ }^{5}$ Here I am following the way McBrayer 2010 frames the issues. 
do you know that what those soldiers did is morally bad, Susan?" Answer: "because I see that it is." 6

Moral perception, its proponents argue, is analogous to ordinary perception in many respects. We have no trouble claiming that we can have perceptual knowledge, under good conditions, of the objects in front of us in ordinary experience. I see the mug on the counter. So, the mug is part of the perceptual content of my experience, from which I conclude that there is a mug on the counter, and therefore that the proposition "the mug is on the counter" is true.

Likewise, moral perception theorists claim that the perceptual states we are in when we see pickpocketing on the subway, wrongful exploitation in the workplace, etc. have the "wrongness" of the act or "badness" of that state of affairs as part of its content. This is so even if it is the case, as some suggest, that the wrongness or badness we perceive is grounded in the ordinary, non-moral empirical data that makes up the content of the perceptual state. ${ }^{7}$ Having moral perception of your bosses exploitative behavior will likely require having the ordinary perception of, for example, seeing him make marks on a page: perhaps he crosses out your colleagues over-time hours because he does not want to pay them over-time. Even if the perceptual state you are in has a mixed content, the moral perception theorist holds that part of that content is moral. ${ }^{8}$

Before turning to Sontag, consider some perceptual states with moral content:

(1) Perceiving that that particular act of pickpocketing is wrong

(2) Perceiving your boss's exploitative behavior as despicable

(3) Perceiving that human beings are capable of unspeakable wrongdoing

(4) Perceiving the world as a bad place

\footnotetext{
${ }^{6}$ This way of thinking about things presupposes that seeing that $\mathrm{p}$ entails that one knows that p. (For a discussion of this thesis see Pritchard 2012).

7 See Audi 2013, 38-9.

${ }^{8}$ But again for doubts about moral perception see Väyrynen 2018. Väyrynen claims that "[positing] distinctively perceptual representations of moral properties would add no explanatory power because a simpler and a more unified account treats their representations in the relevant cases as resulting instead from implicit transitions in thought," (Väyrynen 2018, 110). But note that many moral perception theorists, Wright included, do not take themselves to be committed to claiming that we have perception of moral properties. Rather, their claim is that moral perception is a kind of aspect or factive perception, not property/trope perception (Wright 2007, 5).
} 
Moral perception theorists often focus on examples like (1) and (2). In such cases, the content of the perceptual state of the agent concerns a particular moral wrong. With the literature focused on these sorts of cases, two fairly widespread ideas emerge. First, that moral perception is a skill, something that is possessed by mature moral agents, and second, that moral perception always concerns some particular person's needs. ${ }^{9}$

Mature moral agents can achieve knowledge of the wrongness of (1) and (2) above through a combination of perceiving what takes place and attending to the particular good of the person(s) involved. It is in virtue of the fact that the good of a particular individual is made salient to the mature moral agent in combination with the non-moral facts that the content of their perception has a moral element. Hence, Lawrence Blum claims that "one of the most important moral differences between people is between those who miss and those who see various moral features of situations confronting them" (Blum 1994, 30). Mature moral agents, for Blum, are those who are perceptually sensitive of the needs of others, which enables them to know when they are in a situation where something must be done in support of another's needs - they are the sorts of people who are skilled at perceiving "moral situations as moral situations" (Ibid.)

Moral perception theorists like Blum often object to universalist or impartialist ethical theories that explain the morality of an agent's action in terms of her recognizing the moral rule that applies to her situation. According to such a theory, a moral agent is said to be responsive to the needs of others in a particular case in virtue of there being some general rule which she endorses that says she ought, in such cases, to act in certain ways. As a moral particularist, Blum disagrees with this approach to the morality of action. He argues instead that in order to act in a way that is distinctively moral, the agent must act "from loving attention to particular persons" (Blum 1994, 25). Even if we grant that an agent might be skilled at "perceiving moral situations as moral situations," and that her principles may reinforce perception of this type, she cannot be said to have particular moral knowledge-moral knowledge of the sort that Blum

9 This point is emphasized by Blum (1994), and Wright (2007) follows his lead on this matter. Wright, drawing on empirical research into the nature of "refined perception," defends the view that moral perception is only available to moral agents whose perceptual apparatus is refined. 
thinks is crucial for loving moral action-if the content of her perceptual state is something general like in states (3) and (4) above.

Sontag, however, is not committed to tying moral perception to moral particularity, nor does she hold that the value of moral perception is ultimately a matter of its enhancing our epistemic sensitivity to particular instances of evil. Thus, whereas Blum and others focus on examples of moral perception like (1) and (2) above, Sontag is more interested in examples like (3) and (4). When she asks "[what] to do with such knowledge that photographs bring of faraway suffering?" I suggest that we should read her as speaking about general, as opposed to particular, moral knowledge (Sontag 2003, 99). The Sontagian claim about moral perception that I will defend below is that, in addition to providing us with knowledge of particular moral propositions about the goods and needs of others, perception provides direct knowledge of general moral propositions as well. Contrary to Blum and others Sontag believes there is moral value in perceiving something general about humans in the particular, and, moreover, this kind of perception does not do violence to particularity.

\section{Perceptual Knowledge of General Moral Truths?}

In the cases like (1) and (2) above, there is some particular action or state of affairs that an agent perceives, and part of the content of her perception is that the particular action or state of affairs is wrong or despicable. But in cases like (3) and (4), the perceptual content is different: what the agent perceives is not something particular, but rather something general in the particular. This straightaway raises a question about whether or not there is some inference involved in cases like (3) and (4) such that the general moral knowledge in those cases is not perceptual, but rather inferential. And there is the additional worry of whether such inferences, if they are involved, would be justified, since while some inferences to the general are quite safe, others may not be.

The aim of the following section is to present Sontag's argument for the claim that general moral knowledge can be had by way of perception, and therefore that some perceptual states have as part of their content some general, rather than particular 
moral truths. ${ }^{10}$ I will also show how she addresses the aforementioned worries about the role inference plays in our acquisitions of moral perceptual knowledge.

The first thing to note is that Sontag does not enter the debate about moral perception at the earliest stage of trying to convince a skeptic that there is such a thing

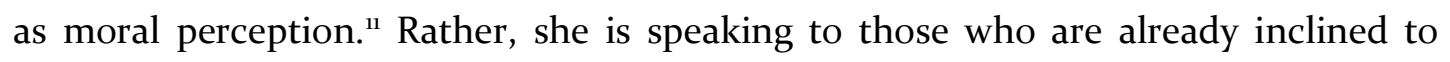
believe that there is such a capacity. Her main argument for the claim that we can have general moral perceptual knowledge appears in her discussion of how war photographs weigh on memory.

She begins by pointing out that "[there] is simply too much injustice in the world. And too much remembering (of ancient grievances: Serbs, Irish) embitters.” (Sontag 2003, 115). Her thought is that there is ethical value in forgetting, since were one to never forget past injustices, it would be difficult to go on living. Less dramatically, if one cannot forget the wrongs done to them by others, then their relations will never recover the form they once had. The point is that there is some good to be had for the Irishmen, whether Protestant or Catholic, who strive to forget what the other side did during The Troubles.

Sontag thus believes that those afflicted by political violence should move beyond the particular harms done to them as best they can and let their desires for retribution subside. "If the goal is having some space in which to live one's life," she says, "then it is desirable that the account of specific injustices dissolve into a more general understanding that human beings everywhere do terrible things to one another" (Sontag 2003, 115-6). This is a normative recommendation about how one ought to go on living after directly experiencing political violence. For many, such a recommendation is already morally problematic. Whether or not Sontag is right to make such a recommendation, I am interested in the epistemic implications of what she says, since these implications bear on the question of moral knowledge.

\footnotetext{
${ }^{10}$ In this way, I see Sontag's work on moral perception to be loosely Moorean in spirit, since she is claiming that knowledge can be legitimately had directly via perception. In a sense, Sontag at times even seems to be offering something analogous to a Moorean proof. How do I know suffering is bad? Here is a picture of it. See Moore 2000.

"Wright has the following nice response to such a person: "[Mature] moral agents do not possess some distinct ['moral sense']: their existing faculties of perception have simply been refined and developed in such a way as to enables them to reliably perceive subtle facts about the moral environment that surrounds them (facts that other moral agents might not perceive)" (Wright 2007, 11).
} 
One such implication is that specific injustices often reveal something general about human beings and the human world. According to Sontag, we ought to "[let] these atrocious images" of injustice haunt us (Sontag 2003, 115). "The images says: this is what human beings are capable of doing-may volunteer to do, enthusiastically, selfrighteously" (Ibid). ${ }^{12}$ Notice the two propositions Sontag gives us to work with here. We can explicitly quote the first as "human beings everywhere do terrible things to one another" (Ibid). The second proposition adds to the first the idea that human beings do these terrible things voluntarily, and so reads as follows: "human beings everywhere voluntarily do terrible things to each other." The idea here is unique not only because of the form of the moral propositions Sontag has in mind, but also because of the way in which she thinks it is possible for us to acquire knowledge of them, namely, perceptually. Two comments about her claim are called for.

First, in the above passage, Sontag speaks about the way humans can come to have a "general understanding" of the above two propositions. That is, she is talking about ways we can come to understand general moral truths by perceiving war photographs, but not explicitly about whether or not this perception gives us knowledge. Depending on how one draws the line between perceptual moral understanding and perceptual moral knowledge, this claim will be more or less striking, perhaps because understanding is epistemically weaker than knowledge. So where does Sontag draw the line between the two? I think it is clear from the surrounding context in which this claim occurs that she does think that the general understanding that she thinks mature moral agents come to have by seeing war photographs is a result of the general moral knowledge that the photographs transmit perceptually. Thus, what is really needed is a defense of the claim that we can have some general moral knowledge by perceiving war photographs. If we can have that, then we will be in a position to fulfill the normative recommendation to forget.

War photographs, according to Sontag, enlarge "our sense of how much suffering caused by human wickedness there is in the world we share with others" (Sontag 2003,114 ). They perform this task by showing "what human beings are capable

\footnotetext{
${ }^{12}$ Shortly after saying this, Sontag tells us not to forget what these photographs show, but then goes on to say that there is some ethical value in forgetting. I am not going to guess where she comes down on this complicated issue.
} 
of inflicting in the way of gruesome, hands-on cruelties upon other human beings" (Ibid). But what about an example of ordinary moral perception? Sontag's claim is that the relevant perceptual states often admit of a particular and a general interpretation. The particular interpretation is the one given to them by Blum and others. But Sontag wishes to claim that the very same ordinary perceptual states can be interpreted as providing agents with moral knowledge of a more general sort in virtue of the same content that Blum and others would cite as providing agents with particular moral knowledge. However, there might be some reasons to doubt that this is true.

As an example, imagine that you were one of the many war photographers sent to document the Vietnam War. To make things even more vivid, imagine you are standing next to Ron Haeberle in the village My Lai in March of 1968. You are taking photographs of the massacre that occurred shortly before you arrived. As far as standard moral perception theory goes, you are in a perceptual state with moral content, which can put you in a position to know an empirical moral truth about the world, namely, that what the marines did to these villagers was wrong (wrong in general, wrong in accordance with the rules of war, etc.). ${ }^{13}$ The idea is that by being in that perceptual state you can also acquire knowledge of a more general empirical moral truth about the world, namely, "that human beings do terrible things to each other" or "that great human suffering is caused by great human wickedness." And this shows that the perceptual state has general as well we particular contents.

However, here one might worry that the perceptual state one is in has only particular contents, and that the move to the general requires an inference. This is problematic for Sontag, since her claim is that we can have general moral perceptual knowledge, not just general moral knowledge that we infer on the basis of some particular moral perceptual knowledge. Moreover, the inference here is potentially unjustified: it would be too quick to assume that people everywhere do wrongful things to each other just by seeing a handful of bad (even atrocious) actions. But all that these worries show is that it is not mere happenstance that Sontag chooses to talk about general moral perceptual knowledge had by looking at photographs, rather than

\footnotetext{
${ }^{13}$ Even with the evaluative context altered as it is during times of war.
} 
through direct perception of the world. It is the uniqueness of photographic perception that forms the basis of her argument.

One of Sontag's main claims is that the ethical value of photographs rests in the fact that they can provide unique opportunities for moral perception that one might otherwise not have. While perceiving such photographs cannot remedy all of the holes in our moral knowledge, they at least present us with "an invitation to pay attention, to reflect, to learn, [and] to examine the rationalizations for mass suffering [...]" (Sontag 2003, 117). Paying attention to, reflecting on, learning about, and examining are activities through which we can acquire certain epistemic goods that enable us to reach moral maturity. As long as such holes exist in one's moral knowledge, then, as Sontag says, they will not have "reached moral or psychological adulthood" (Sontag 2003, 114). The implication is that in order to reach moral adulthood one must possess moral knowledge of not only particular moral wrongs, but of general moral wrongs as well. And one of the ways to justifiably achieve this knowledge is by studying the photographic record.

As it turns out, war photographs are particularly well-suited for providing the sort of general moral knowledge Sontag is interested in, and thus they meet the worries about justification mentioned above. This is in virtue of their being aesthetic objects. I already argued above that the aesthetic value of documentary war photographs can be thought of as being a matter of the cognitive benefits such photographs provide. Now we see that one of those cognitive benefits is that they provide general moral knowledge of human evil and wickedness. This adds to our thinking about their aesthetic value the idea that documentary photographs succeed aesthetically to the extent that they provide opportunities for epistemic (and also moral) enrichment.

It is because war photographs are aesthetic objects that they can provide these sorts of cognitive benefits. According to at least some aesthetic theories, such as Arthur Schopenhauer's, an aesthetic object, like a photograph, provide epistemic opportunities that are unavailable in other parts of life. This is because aesthetic objects provide their audience with an opportunity to contemplate general, as opposed to particular, ideas. We might refer to this as the capacity of aesthetic objects to make certain ideas salient to us. As the argument goes, aesthetic contemplation provides a focused form of contemplation, one removed from ordinary human concerns. This 
allows the audience to contemplate certain general ideas that they may miss in ordinary life. ${ }^{14}$

Applied to Sontag, the idea is that war photographs can make the truth of certain general moral propositions salient to us, and especially to those of us prone to a false moral optimism. They do this in virtue of the fact that, as aesthetic objects, they are suited to presenting general ideas, things like the idea of the world as a terrible place. This nicely avoids an objection that has been lingering about our discussion of Sontag's views on moral perception, which says that general moral perceptual knowledge is in fact not perceptual knowledge at all, but inferential knowledge. I think this objection has some legs when applied to ordinary moral perception. Maybe it is true that in a direct case of moral perception, one is not justified in claiming to have seen that some general moral proposition is true. However, war photographs can block this move, since they have certain features that make them ripe to convey this sort of knowledge directly, namely, they express general ideas.

My construal of the aesthetic and epistemic value of war photographs also blocks another familiar objection to cognitivist views of the arts. Jerome Stolnitz (1992) famously argued that the knowledge conveyed by works of art is of a trivial sort. Anything we can come to know about the world by engaging with a work of art is something we could know through some other means. Thus art has no special cognitive value. Moreover, as the objection goes, whatever cognitive benefits there are from engaging with art will not bear on art's value as art. ${ }^{15}$ The objection from triviality misses the mark here, since the general moral knowledge had by perceiving photographs is precisely not the sort of knowledge we would be justified in saying we acquired simply by seeing a few bad things happen in ordinary life. Even if it would be possible for one to acquire this sort of general moral knowledge through some nonaesthetic means, we could still defend the cognitive value of documentary photographs in terms of their making certain features of the world morally salient to individuals who might not otherwise have the chance to confront them. This, in fact, is what Sontag

\footnotetext{
${ }^{14}$ This, in admittedly too rough an outline, gives the general flavor of Schopenhauer's views in Book III of The World as Will and Representation, Schopenhauer 2010.

${ }^{15}$ Stolnitz 1992, 191.
} 
thinks they do. They make moral truths about human evil salient to those privileged enough to never have to confront them directly. ${ }^{16}$

\section{Two Problems for Moral Sentimentalism}

Though Sontag aims to make us aware of the epistemic value of war photographs, her real concern is with their moral value. Again, the guiding question of $R P O$ is: "What to do with such knowledge as photographs bring of faraway suffering?” (Sontag 2003, 99). The previous section treated the epistemic part of her question. This section will treat its moral or practical part.

Throughout RPO, Sontag exercises caution when discussing the actions, attitudes, and emotions that our knowledge of suffering prescribes. The modern moral sensibility, she says, "regards suffering as something that is a mistake or an accident or a crime. Something to be fixed. Something to be refused. Something that makes one feel powerless" (Sontag 2003, 99). Suffering can evoke a wide, conflicting range of evaluative responses. In regarding it as a mistake or a crime, we evaluate it is bad or wrong. In taking it as something to be fixed, we regard it is providing some motivation for us to act to alleviate it. And yet, in making us feel powerless, we regard it as something that we cannot do anything about. This later evaluation explains how it is that our witnessing suffering can become voyeuristic. And so Sontag says that "[perhaps] the only people with the right to look at images of suffering [...] are those who could do something to alleviate it [...] or those who could learn from it. The rest of us are voyeurs, whether or not we mean to be" (Sontag 2003, 42) ${ }^{17}$

Sontag's remarks on suffering's voyeuristic allure caution against assuming that other people's suffering prescribes a unitary response, while also questioning the practical value of the moral emotions that witnessing suffering often evokes. In this

\footnotetext{
${ }^{16}$ More needs to be said here to show whether photographs are uniquely suited to provide this kind of moral perceptual knowledge, since at first glance it seems a historical painting ought to as well.

${ }^{17}$ Here Sontag suggests that moral perception theorists should consider the issue of when a moral subject is entitled to certain moral perceptual states, and when she is not. The notion of perceptual entitlements that typically gets discussed in literature on perception is usually tied to an epistemic notion of justification, whereas here Sontag seems to be speaking about a notion of moral justification and its relation to perception.
} 
section I will draw out the implications of these ideas for the metaethical theory they most directly effect, namely, moral sentimentalism.

In a recent volume on moral sentimentalism, Remy Debes and Karsten R. Stueber state that moral sentimentalists "are unified by a conviction in the 'responseinvoking' nature of (at least some) ethical concepts or judgments; that is, the thesis that (at least some) ethical concepts or judgments must be analyzed in terms of human emotional responses (broadly construed)" (Debes and Stueber 2017, 1). For example, according to some moral sentimentalists, the basis for judging that an action is 'wrong' is a feeling of disapproval towards that action. Rather than linger over the moral sentimentalist's account of moral judgment, however, I want to examine more closely the value they attribute to certain moral emotions, particularly those evoked in response to human suffering.

The moral sentimentalist's list of favorite moral emotions ${ }^{18}$ runs long, but we can be sure that somewhere on that list will fall a variety of explicitly other-regarding emotions like sympathy, empathy, and compassion. These emotions are evoked by witnessing another human being's suffering, and many moral sentimentalists think that human beings who feel sympathy, compassion, and empathy for another's suffering are morally good in at least some respects. I will focus on sympathy and compassion here, since Sontag refers to them in discussing the practical value of war photographs.

Sontag's most striking remarks about sympathy occur in the following passage, already quoted in section 2 :

So far as we feel sympathy, we feel we are not accomplices to what caused the suffering. Our sympathy proclaims our innocence as well as our impotence. To that extent, it can be (for all our good intentions) an impertinent-if not an inappropriate-response (Sontag 2003, 102).

The main problem that Sontag brings to the moral sentimentalist's attention here is one of content. Emotions like sympathy and compassion purport to have the subject's

\footnotetext{
${ }^{18}$ I will use the terms moral emotions and moral sentiments interchangeably.
} 
innocence and impotence as part of their content when, in fact, in some important cases, this is not the case. Since this problem concerns both a subject's false innocence and her false impotence, I will break the problem into two parts: The Innocence Problem and The Impotence Problem.

The Innocence Problem for moral sentimentalism says that certain otherregrading moral sentiments, in this case sympathy, can be problematic for the reason that they include the innocence of the agent experiencing them as part of their content. But in many cases, the agent who feels sympathy is in fact not innocent. Therefore, in certain cases, the content of sympathy is false or illusory. If Sontag's view is correct, this might seriously jeopardize both the moral and epistemic value of certain otherregarding emotions. Let us explore the details of her claim.

The "content" of an emotion would seem to be that which the emotion is about or that which it is directed at. ${ }^{19}$ An emotion like sympathy typically has another person's suffering (or maybe we want to say their good) as part of its content. One might claim that since emotions have content, they are a kind of quasi-judgment. One's feeling fear, for example, can be understood as proclaiming something about their environment: that something threatening might be lurking around the corner. Similarly, one's feeling sympathy proclaims something about one's environment, namely, that someone is suffering. The passage above, however, shows that Sontag's idea is that sympathy does not just proclaim something about the object which it is directed at, but also something about the subject who feels it. By contrast, the standard view in moral sentimentalism is that emotional responses are primarily or exclusively object-directed.

Famously, some non-cognitivist moral sentimentalists have used the language of 'projection' in arguing that our emotional responses project certain properties onto natural objects. It is in virtue of these projections that natural objects then acquire their

\footnotetext{
${ }^{19}$ This is just a stab. I am not deeply committed to a cognitive theory of the emotions. More to the point, Sontag's criticisms here would apply to anyone who gave a central role in moral life to certain moral emotions, regardless of their subsequent account of the content (or lack thereof) of the emotions. If one wishes to claim that emotions have no content, then her criticism can just move on down the line and focus on the normative issue of the inappropriateness of certain emotions in certain situations, regardless of their contents.
} 
emotional or moral significance for us. ${ }^{20}$ Applied to moral agents, the idea is that if we notice someone in distress, we might feel sympathetically towards them, and from that feeling we might find ourselves judging that their situation ought not to be, and that we should do something to help. As of yet, there does not seem to be anything false in the content of one's sympathy. However, this is because we have not yet taken into account what our sympathetic feeling says about us. And this is where Sontag's remarks prove insightful.

To get a sense for Sontag's insight, imagine a situation where, walking down the street, you see a cyclist crash and injure herself. You feel sympathy for her. What is the content of this feeling? Part of it is the suffering of the cyclist. But the full moral weight of the feeling cannot be assessed by attending only to its intentional object. So we have to ask what your sympathy says (or does not say) about you. One obvious thing it says is that you are averse to what happened to the cyclist. It might also say that you ought to help. Finally, what will not be part of the content of your sympathy is that you are guilty, and you might come to know this by asking yourself if you had anything to do with what just happened, to which you answer "no." So there is nothing morally problematic in this case; therefore the content of your sympathy is neither false nor illusory.

But now imagine you are browsing the internet and you come upon a photograph documenting an atrocity of war (the My Lai massacre, a young Serbian soldier kicking a dying Bosnian woman, a victim of the Rwandan genocide, and so on). You feel sympathy for these human beings, or even better, perhaps you feel compassion for them. Again, part of the content of this feeling is their suffering, since that is what the feeling is directed at. But feelings are not just intentional, but reflexive. And if you were to ask yourself whether or not you are in anyway implicated in what you see, depending on the context, you may very well be. But then while your sympathy

\footnotetext{
${ }^{20}$ While it is by no means clear whether Hume himself was a projectivist of this sort, his remark in the final paragraph of the first Appendix ('Concerning Moral Sentiment') to An Enquiry concerning the Principles of Morals, Hume 1975 has been influential among moral sentimentalists, whether of a Humean or some other stripe. There, he says that "taste," which he appears to view as synonymous with sentiment, "has a productive faculty... gilding or staining all natural objects."
} 
proclaims that you had nothing to do with what you see, this is false. Therefore, as Sontag sees it, feeling sympathy is impertinent and inappropriate.

You can be innocent only if you are not an accomplice to what caused the suffering. Are you? Sontag implies that if you were directly involved in bringing to power the regime that is responsible for the suffering you witness, then you are an accomplice, and therefore not innocent. However, even if you were not directly involved in bringing that regime to power, you might remain a citizen of the country (United States, Serbia, and Rwanda) in which the incidents took, and perhaps continue to take place. Or, more likely, you are a citizen of a country who in some way, shape, or form supports the regime responsible for the atrocity you witness.

For Sontag, your being in such a relation to the suffering you perceive follows from the fact that, in an increasingly globalized world, "our privileges are located on the same map as their suffering-and may, in ways we'd prefer not to imagine-be linked to their suffering" (Sontag 2003, 102-3). ${ }^{21}$ Part of the content of your sympathy, therefore, is false or illusory in virtue of what it proclaims about you. Sontag is not claiming that it always inappropriate to feel emotions like sympathy. Rather, she is claiming that it is inappropriate to feel them in certain important cases, for instance, when members of the privileged class of society witness the atrocities committed by their country. She thus gives us distinctive reasons to doubt the moral and epistemic significance of moral emotions like sympathy and compassion.

One final piece of evidence we might cite for Sontag's views is the fact that, as she says, "morally alert photographers and ideologues of photography have become increasingly concerned with the issues of exploitation of sentiment (pity, compassion, indignation) in war photography and of rote ways of provoking feeling" (Sontag 2003, 8o). The fact that these sentiments can be exploited in ways that may be neither prudent nor morally efficacious is partially explained by The Innocence Problem. A photograph has failed its moral purpose if it arouses emotions with false or illusory content.

\footnotetext{
${ }^{21}$ Sontag mostly focuses on incidents perpetrated by the Western powers. I certainly am not suggesting that a country that is a victim of Colonialism, the effects of which could perhaps be cited in explaining what led to genocide, is afforded the Western privileges that Sontag speaks of in this passage.
} 
What about what I am calling The Impotence Problem for moral sentimentalism? Here the claim is that the content of certain emotions is false not just in virtue of their professing an agent's innocence, but also in virtue of professing her impotence. In some cases, then, it is part of the content of sympathy or compassion that the one who feels it is powerless; they are incapable of doing anything about it.

Perhaps unsurprisingly, a similar criticism was raised against sentiment-based ethics by another fierce social critic, and one whose voice has equally been neglected by contemporary metaethics: Theodor Adorno. ${ }^{22}$ In the spring and summer of 1963 , Adorno delivered a series of lectures on the problems of moral philosophy. In the final lecture of that series, Adorno offers the following criticism of Schopenhauer's ethics of compassion, which carries over to other forms of moral sentimentalism.

[The] concept of compassion tacitly maintains and gives its sanction to the negative condition of powerlessness in which the object of our pity finds himself. The idea of compassion contains nothing about changing the circumstances that give rise to the need for it [...]. We may conclude from this that the pity you express for someone always contains an element of injustice towards that person; he experiences not just our pity but also the impotence and the specious character of the compassionate act (Adorno 2001, 173-4).

Adorno's claim that the feeling of compassion "contains nothing about changing the circumstances that give rise to the need for it" can be read as the claim that compassion has as part of its content the idea that the circumstances cannot be altered. In other words, his main criticism of compassion is that it merely affirms the social conditions in which suffering arises. He then goes on to call the compassionate act itself impotent, since it cannot effect any change in the world.

Sontag and Adorno thus agree that, sometimes, it is part of the content of sympathy and compassion that nothing can be done. They may also agree on the motivational issue of the compassionate act itself being impotent, and being

\footnotetext{
${ }^{22}$ Freyenhagen 2013 is an exception: an excellent study of Adorno's normative and metaethical views that does a nice job of linking some of his ideas to certain contemporary stances in the literature, e.g. Aristotelian naturalism, Kantian metaethics, etc.
} 
inappropriate for that reason. Sontag, however, seems less sure of this than Adorno. She seems to think that compassionate acts are not always impotent. The important thing is simply that agents must act on their compassion, before it "withers" (Sontag 2003, 101).

The main upshot of these criticisms for the moral sentimentalist is that the content of the emotional responses they take to be central for morality has to be treated with more subtlety and care. This means appreciating what certain emotions say about the person who has them as much as appreciating what they say about others. If the basis of our moral judgments and convictions is to be sought in our emotional responses, and some of these emotional responses contain false or illusory content about the subject, then they will have to be further scrutinized if they are to have the value the moral sentimentalist assigns to them. In other words, she must appreciate the reflexive, and not just the reactive element of sympathy and compassion.

Sontag is not denying that it is a morally good thing to react to another's suffering by feeling sympathy or compassion for them. Indeed, such feelings often naturally motivate agents to act in ways that will contribute to alleviating that suffering. Her point is that taking these emotional responses to be all-things-considered good is inconsistent with the troubling human tendency to (a) do nothing about that for which they feel sympathy, and (b) to read off of one's sympathy one's own moral virtue, and their moral exculpation from whatever it is that demanded that emotional response.

A moral sentimentalist might respond to The Impotence Problem by claiming that Sontag is not operating with the right conception of the relevant moral emotions. Sympathy and compassion, they argue, are conceptually tied to motivation. Michael Slote makes almost exactly this point in a recent paper (Slote 2017). Sympathy and compassion, or as Slote prefers to talk about, empathy, must include as its intentional object "the other person's feeling(s) or emotion(s)" (Slote 2017, 8). But if an agent is relating empathically to another's distress, then they in fact feel distressed too. Therefore, "one ipso facto has some motivation to do away with or lesson" the other's pain (Ibid). It is available to Slote and others to argue that in order to be in an emotional state like sympathy or empathy, that state must have the right motivational contents. Impotence, naturally, is not the right motivational contents. So Sontag is not even talking about the sorts of emotions that the moral sentimentalist is interested in. 
The Innocence Problem proves more difficult for the moral sentimentalist. Squabbling over what is and what is not part of the content of a given moral emotion does not seem the way to go here. And even if the Impotence Problem can be met by noting that certain moral emotions must motivate and bring about changes in circumstance to count as the very moral emotion in question, it still could be that such emotions profess our innocence. Thus it is in her unveiling of the Innocence Problem that Sontag exhibits her genuine utility for contemporary metaethics.

What this shows is that metaethicists and moral philosophers interested in the moral emotions have not paid sufficient attention to their reflexive character, that is, what the emotions say about the subject who feels them, and the interesting issues it raises. One research area that might directly benefit by engaging with Sontag's views is work on the reactive attitudes, those attitudes which, as Michelle Mason has recently put it, "respond to the wrong and the bad in human action and character" (Mason 2017, 153).

The reactive attitude theorist is interested in showing that attitudes like resentment, holding one in contempt, guilt, etc. have a serious role to play in moral life. But in doing so, it is often taken for granted that, for instance, the value of one's attitude of contentment towards another's action or character is cashed out purely in terms of the appropriateness of the reaction. Feeling contempt is taken to count in favor of a negative evaluation of the actions or character of another. But what the reactive attitude theorist ignores is what this response says or reflects about the agent who has it. Sontag's general lesson, I think, is that we need to ask what such reactions say about ourselves. Just as it can be morally problematic to continue to feel innocent in the face of suffering, so it can be morally problematic to allow one's emotional reactions to pass as unreflective signals of the moral truth. ${ }^{23}$

\footnotetext{
${ }^{23}$ I would like to thank my fellow presenters at the 2018 Lost Voices at the Foundations of Ethics conference held at the University of Washington, Seattle, first for their congeniality, and second for their helpful comments and probing objections to an earlier version of this essay. Special thanks to Colin Marshall for his generous (and plentiful) comments on several drafts of this essay. I'd also like to thank Dave Fisher, Kevin Mills, Sandy Shapshay, Ivan Verano, and Allen Wood for discussing these issues with me.
} 


\section{References}

Adorno, T.W. Problems of Moral Philosophy, trans. R. Livingston, Cambridge: Polity Press, 2001.

Audi, R. Moral Perception. Princeton: Princeton University Press, 2013.

Blum, L. Moral Perception and Particularity. Cambridge: Cambridge University Press, 1994 .

Cullison, A. “Moral Perception”, European Journal of Philosophy 18, 2009: 159-175.

Dancy, J. "Moral Perception", Proceedings of the Aristotelian Society Supplementary Volume 84, 2010: 99-117.

Debes, R and Stueber, K. R. “Introduction”, In Ethical Sentimentalism, ed. R. Debes and K.R. Stueber. Cambridge: Cambridge University Press, 2017: 1-14.

Hume, David. Enquiries concerning Human Understanding and concerning the Principles of Morals, ed. L.A. Selby-Bigge, Oxford: Clarendon Press, 1975.

Freyenhagen, Fabian. Adorno's Practical Philosophy: Living Less Wrongly. Cambridge: Cambridge University Press, 2013.

Mason, M. "Reactive Attitudes and Second-Personal Address", In Ethical Sentimentalism, ed. R. Debes and K.R. Stueber. Cambridge: Cambridge University Press, 2017: 153-170.

McBrayer, J. P. “A Limited Defense of Moral Perception”, Philosophical Studies 149, 2010: 305-320.

McGrath, S. "Moral Knowledge by Perception", Philosophical Perspectives 18, Ethics, 2004: 209-228.

McGrath, S. "Normative ethics, conversion, and pictures as tools of moral persuasion", In Oxford Studies in Normative Ethics, Vol 1, 2011: 268-294.

Moore, G.E. "Proof of an External World", In Epistemology: An Anthology, ed. E. Sosa and J. Kim. Malden, MA: Blackwell Publishers, 2000: 24-26.

Pritchard, D. Epistemological Disjunctivism. Oxford: Oxford University Press 2012.

Schopenhauer, A. The World as Will and Representation Vol. 1, trans. and ed. Judith Norman, Alistair Welchman, and Christopher Janaway, Cambridge: Cambridge University Press, 2010.

Slote, Michael. "Yin-Yang and the Heart-Mind", Dao: A Journal of Comparative Philosophy 17, 2017: 1-11. 
Sontag, S. On Photography. New York: Picador, 1977.

Sontag, S. Regarding the Pain of Others. New York: Picador, 2003.

Stolnitz, J. "On the Cognitive Triviality of Art", British Journal of Aesthetics 32, 1992: 191200.

Väyrynen, P. “Doubts about Moral Perception”, In Evaluative Perception, ed. Anna Bergqvist and Robert Cowan. Oxford: Oxford University Press, 2018: 109-128.

Walton, K. “Transparent Pictures: On the Nature of Photographic Realism”, Critical Inquiry 11, 1984: 246-277.

Wright, J. "The Role of Moral Perception in Mature Moral Agency”, in J. Wisnewski (ed.) Moral Perception. Cambridge, MA: Cambridge Scholars Publishing, 2007, 1-24. 